\title{
Derrida, Semiotics and Justice
}

\author{
Jacques de Ville
}

Published online: 9 April 2010

(C) Springer Science+Business Media B.V. 2010

This Special Issue of the International Journal for the Semiotics of Law celebrates the contribution of Jacques Derrida (1930-2004) in relation to semiotics and justice. The brief to contributors was to specifically explore the relation between the 'earlier' texts of Derrida on language and the 'later', seemingly more politicoethical texts such as 'Force of law' [1, pp. 228-298]. All the essays in the collection point to the continuity in Derrida's thinking which appears from a careful reading of these texts, thereby contesting the idea of an 'ethical turn'.

We are particularly fortunate to publish as part of the Special Issue, for the first time in English, an interview with Derrida, stemming from 1998, headed "The tragic, the impossible and democracy". In the interview Derrida clarifies a number of issues in relation to his thinking on ethical, legal and political issues. He furthermore provides added insight, ably spurred on by the interviewers, regarding his relation to Heidegger, Levinas, Freud, and Schmitt and, moreover, gives a lucid reading of some of his own texts. The whole interview is worth giving minute attention to. If one had to highlight something specific, Derrida's reflections on the impossible deserve mention in the present context. In 'Force of law', Derrida specifically notes that "[j] ustice is an experience of the impossible" [1, p. 244]. As is pointed out by Derrida in the interview, the impossible 'is' that which we 'desire', which calls on us, and, moreover, puts us in motion. The two references to Freud's death drive in close relation to the impossible in the interview are of critical importance in this respect. In the interview Derrida furthermore cautions that one should be careful to distinguish between 'the impossible', which is at stake in deconstruction, and that which is 'merely impossible'. This important distinction is unfortunately very often ignored in commentaries on Derrida. The impossible is also called by other names in the interview, for example madness, the democracy to come, absolute hospitality, the night, the monstrous, chaos, and the future as such.

J. de Ville $(\bowtie)$

Faculty of Law, University of the Western Cape, Cape Town, South Africa

e-mail: jdeville@uwc.ac.za 
An important question posed to Derrida in this respect is what one's attitude should be concerning this monstrosity. Should it be embraced or does one need to stand firm in the face of it? As appears from Derrida's response, the answer one gives to this question is dependent on one's stance towards the metaphysics of presence. Should one view it from within metaphysics, the tendency will be to view the monstrosity as something bad, such as Hobbes's war of all against all, which needs to be resisted. However, if one understands the monstrous in terms of a structural law which is always at stake, a double law, as something which simply happens, which overtakes us beyond metaphysical oppositionality, an affirmation is instead called for. As Derrida puts it in the interview:

I affirm the impossible, that is, I desire this pure hospitality, even when I cannot afford it. Even when I cannot experience it as such, I say "yes" to the possibility of the impossible.

All of the essays in this Special Issue engage in some way or another with this affirmation of the impossible in Derrida's thinking, as well as its intersection with law and language. Marian Hobson in "Laws and universality, laws and history" finds a strategy at work in 'Force of law' which is analogous to two of Derrida's earlier (1967) essays on Lévi-Strauss and on Foucault. She points specifically to Derrida's insistence in his reading of these texts on drawing a rigorous distinction between what is universal and what merely contingent. Insofar as Levi-Strauss is concerned, Hobson reiterates Derrida's detection in Of grammatology [2] of a contradiction in his (Levi-Strauss's) condemnation of writing. These contradictions are as we know not simply accidental, but necessary insofar as they show the difficulty metaphysics has in dealing with writing, which it associates with the loss of the proper, with blind and empty repetition, with death [2, pp. 17, 25]. Associating writing with violence (and here I am glossing Hobson's text) LeviStrauss dreams of a Rousseauian state of nature, associated with the non-violent purity of the voice, with full and immediate self-presence [2, p. 115]. The desire for self-presence (expressed for example in the prohibition of the revealing of "proper names') is a (universal) secondary reaction against this originary violence, the loss of self-presence, of the proper, the inscription always-already within a system of differences, followed at times (contingently) by a third violence (here, the revealing of proper names). We also find this (universal) structural law operating in Foucault's discourse on madness, as Hobson points out. Foucault views the relation between madness and reason in historical and thus empirical terms, and consequently remains blind to the fact that language itself is structured in terms of reason, having to exclude 'madness' from the beginning, from its moment of awakening. Foucault thus seeks to write a history of madness, to let madness itself speak, by relying on the language of reason. As Hobson, however, notes, "[t]he separation of madness and reason cannot ... be treated as an actual historical event". This 'contradiction' again does not simply constitute an oversight on the part of Foucault, but shows the operation of metaphysics, being necessarily blind to its own (continuing) suppression of total madness ('liberation from reason' as Hobson has it). In 'Force of Law' Derrida shows that a similar denegation is at work in the positing of a legal system. That which is necessarily excluded in law's constitution, in a similar way in 
which Levi-Strauss seeks to exclude writing, and Foucault the madness constitutive of language, is referred to by Derrida as 'justice'.

In "Law, genre and the voice of the friend" Elina Staikou invokes the double meaning of law, and enquires with reference to Derrida's earlier texts specifically into the law before the law, or what Derrida elsewhere refers to as justice or friendship. The title furthermore alludes to Derrida's essay "The Law of genre" [3, pp. 221-252] as well as Heidegger's elusive invocation of the 'voice of the friend' in Being and time [4]. Law understood as genre, refers to all determined forms of law, including natural law and positive law. As Staikou points out, these determined forms of law stand in tension with what can be termed "degenerescence", that is, "a law of impurity at the heart and origin of all law". She uses this notion and others forming part of the same (open) chain of "new" concepts, such as the trace, sexual difference, general phantasmatics, and generalised fetishism, to explicate what is at stake in 'the law' (understood in the above sense) as well as in Derrida's analysis of friendship. Staikou traces Derrida's views on friendship and justice as far back as his deconstruction of the Saussurian sign in Of grammatology [2]. Saussure's sign, as Staikou points out, makes a natural link between the voice and sense, which corresponds with that traditionally made between phusis and nomos, natural birth and citizenship. The sign constitutes a reduction and determination of the trace, like the symbol, nature and law. The trace, Staikou notes, "can never be erased without leaving a trace of its own erasure, which it thus bears in its very structure and which remains impossible to master". Heidegger's "voice of the friend" is taken up towards the end of the essay and it is specifically when Staikou refers to Derrida's reading of this passage as wide enough to include the voice of the stranger and adds that 'the call comes "as if it dictated a kind of law" ", that one is tempted to read this in close association with Freud and more specifically the 'desire for the impossible' that Derrida speaks of in the interview included in the Special Issue. At stake in Derrida's analysis of friendship, as she points out, is "a friendship prior to friendships at the origin of all law".

Linnell Secomb in "Derrida's other ends of man" focuses on three of Derrida's texts, which were all 'events' in New York and which reflect on questions of the greatest political, ethical and legal importance: 'The ends of man' [5, pp. 109-136], presented in New York in 1968 at the time of the Vietnam war; 'Force of law: The mystical foundation of authority' [1], presented in New York in 1989 and which partly deals with the holocaust; and an interview with Borradori in Philosophy in a time of terror [6], again in New York, shortly after the events of September 11, 2001. Linking these texts together, the author shows the continuity in Derrida's thinking in relation to humanism and the Enlightenment. Starting with 'Force of law', the author points to the inextricable relation Derrida posits between justice and law, as well as his expression of support for the emancipatory ideals and for human rights. At the same time Derrida seeks to rethink these in a radical way. Secomb reads Derrida as adopting a similar stance in relation to humanism in 'The ends of man', which is the main focus of her essay. Analysing Derrida's reading of Hegel, Husserl and Heidegger, she shows how humanism is both exceeded and retained in their thinking, the latter because of their continuing reliance on metaphysical concepts. The author reads Derrida as not simply opposing or rejecting humanism, 
but as making a 'non-oppositional deconstructive gesture in relation to humanism' a position which is 'more-than-humanist'. According to the author a similar approach is adopted by Derrida in the interview in Philosophy in a time of terror in relation to the state. It is not enough to simply oppose the state. Instead it should be rethought in its relation to autoimmunity or what can also be termed unconditional hospitality. Secomb concludes with a reading of the post-scriptum of 'Force of law', showing how Derrida's reading of Benjamin assists us in understanding the 'nature' of the deconstructive gesture, as compared to one of destruction. One can detect the beginnings of a debate about the postscript in 'Force of law' from the texts of Secomb and Hobson, which Staikou incidentally elaborates on elsewhere [7].

Jacques de Ville in "Revisiting Plato's pharmacy" analyses a text of Derrida which played an important role in the early reception of Derrida in the legal context. By analysing the relation between this text of Derrida and a number of Freud's texts relating to dreams, sexuality, desire, and death, the author shows the importance of a certain reading of Freud in understanding 'Plato's pharmacy' [8, pp. 67-186]. In the essay, the speech/writing opposition is explored again, and Freud's death drive is invoked to understand the notion of arche-writing which according to Derrida lies at the 'pre-origin' of this opposition. The pharmakon and the pharmakos, as well as Derrida's deconstruction of the metaphysical inside/outside distinction, can similarly be better understood with reference to Freud's reflections on the death drive. The movement from mythos to logos is likewise shown to involve a 'casting out' of that which is on the 'inside', to the 'outside', that is, of (the desire for) death. In comparing this early text of Derrida with Force of law [1], the author shows that the pharmakon has a similar structure as 'justice'. In the case of both 'concepts', a desire for presence, privileged by metaphysics, as well as a 'desire' for death, 'suppressed' by metaphysics, are at stake. In Derrida's analysis of these concepts it is shown that the two desires are in a differantial relation with each other. Both these desires in other words 'inhabit' these concepts and at the same time lead to their auto-destruction. This has extremely important implications for law, ethics, and politics.

Acknowledgments A word of thanks must go to Anne Wagner for initiating this project, to Michael Naas for his advice, to Danie Goosen for his support, and to the contributors for their efforts.

\section{References}

1. Derrida, Jacques. 2002. Acts of religion. New York: Routledge.

2. Derrida, Jacques. 1974. Of grammatology. Baltimore: The John Hopkins University Press.

3. Derrida, Jacques. 1992. Acts of literature. New York: Routledge.

4. Heidegger, Martin. 1962. Being and time. San Francisco: HarperCollins.

5. Derrida, Jacques. 1982. Margins of philosophy. Chicago: University of Chicago Press.

6. Borradori, Giovanna. 2003. Philosophy in a time of terror: dialogues with Jürgen Habermas and Jacques Derrida. Chicago: University of Chicago Press.

7. Staikou, Elina. 2008. Justice's last word: Derrida's post-scriptum to Force of law. Derrida Today 1: 266-290.

8. Derrida, Jacques. 2004. Dissemination. London: Continuum. 